\title{
New insight into the molecular phylogeny of the genus Liparis s.l. (Orchidaceae: Malaxideae) with a new generic segregate: Blepharoglossum
}

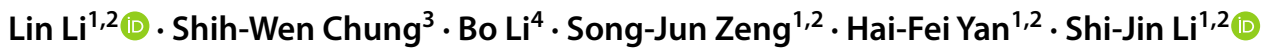

Received: 14 April 2019 / Accepted: 31 March 2020 / Published online: 3 May 2020

(c) The Author(s) 2020

\begin{abstract}
Molecular studies have shown that Liparis s.l. is polyphyletic, with the epiphytic Liparis alliance well separated from the clade representing Liparis in its restricted sense and further forming a phylogenetically heterogeneous assemblage. The generic status of Cestichis, as the key member of the epiphytic Liparis alliance, remains contentious, and the relationships between Cestichis, Stichorkis and Platystyliparis are still unclear and in need of further studies. We herein employ DNA sequence data from nuclear ITS and plastid matK regions to clarify the generic boundaries of Cestichis and its relationship to the allied genera. Results from both Bayesian inference and maximum likelihood analysis congruently indicate that Cestichis as currently circumscribed is not monophyletic. The Blepharoglossum clade, corresponding to commonly recognized sect. Blepharoglossum, forms a monophyletic lineage closely related to the genus Oberonia instead of the core Cestichis clade. A re-evaluation of the diagnostic morphological characters reveals that this lineage represents a morphologically distinct group. Based on these results, Blepharoglossum is removed from Cestichis and elevated to generic status. Our study also sheds light on the homoplastic nature of some diagnostic morphological characters used traditionally in the taxonomy of the Malaxidinae.
\end{abstract}

Keywords Blepharoglossum $\cdot$ Cestichis $\cdot$ Liparis $\cdot$ Malaxideae $\cdot$ Platystyliparis $\cdot$ Stichorkis

\section{Introduction}

The genus Liparis Rich. in the tribe Malaxideae (Epidendroideae, Orchidaceae) is large and diverse, encompassing more than 320 species distributed worldwide from the tropics and subtropics to temperate and alpine regions. Despite its cosmopolitan distribution, the majority of the species diversity occurs in Southeast Asia, the Malay Archipelago, the Philippines and New Guinea, extending as far as Africa, Australia, Americas and Europe (Comber 2001; Pearce and Cribb 2002; Pridgeon et al. 2005). This broad generic concept of Liparis has been adopted in numerous regional floristic treatments (Seidenfaden 1976; Comber 2001; Pearce and Cribb 2002; Chen et al. 2009). However, over the past decades, there has been a trend toward splitting of Liparis into smaller genera, including Cestichis Thouars ex Pfitzer, Stichorkis Thouars, Platystyliparis Marg. and Alatiliparis Marg. \& Szlach. (du Petit Thouars 1809; Pfitzer 1887; Margońska and Szlachetko 2001; Jones and Clements 2005; Margońska 2006). These classifications were primarily based on morphological characters. The status of 
these genera, however, has not been generally accepted by taxonomists.

Molecular studies have shown Liparis under its current circumscription is polyphyletic, with species basally diverged into two groups: the terrestrial group and the epiphytic group (Cameron 2005; Li and Yan 2013; Tang 2013; Tang et al. 2015). Those studies support neither the monophyly of Liparis in its traditional circumscription, nor its infrageneric classification (Garay and Romero-Gonzalez 1999). Consequently, the composition of the genus Liparis s.s. was restricted to a temperate terrestrial group (Pridgeon et al. 2005), the remaining species of the genus (Liparis pro parte), and the species of the epiphytic Liparis were removed to the genera Cestichis, Stichorkis, Platystyliparis and Alatiliparis. This group forms a heterogeneous assemblage of mostly epiphytic species of Liparis sensu lato with coriaceous and conduplicate leaves that exhibits high morphological diversity, most notably in floral variations and inflorescence architectures. It comprises about 200 species that are predominantly found in the Old World tropics (Seidenfaden 1976; Comber 2001; Pridgeon et al. 2005). Still, we know very little on the diversity patterns of most groups constituting this assemblage, which includes approximately $70 \%$ of the species diversity of Liparis and is an important component of the Paleotropical flora.

As the largest epiphytic member of the Liparis alliance, Cestichis has long been much debated. It was formerly subsumed in Liparis as a section (Lindley 1830; Garay and Romero-Gonzalez 1999) or subgenus (Schlechter 1914), while others preferred to consider it as a separate genus (Pfitzer 1887; Jones and Clements 2005). There has been much confusion concerning the taxonomic status and delimitation of Cestichis (Pridgeon et al. 2005). So far, it has been unclear whether Cestichis as currently circumscribed is monophyletic. The phylogenetic relationships between Cestichis and the currently recognized genera Stichorkis and Platystyliparis remain poorly understood.

In the present study, we investigated the phylogenetic relationships among the major lineages of the epiphytic Liparis alliance, with special emphasis on species of Cestichis and its allied genera. Phylogenetic analyses were performed with two widely used molecular markers, the internal transcribed spacers of the 18S-5.8S-26S nuclear ribosomal DNA (collectively, ITS of nrDNA), and chloroplast gene encoding for Maturase $\mathrm{K}$ (matK). The aims of this study are to: (1) assess the generic limits and monophyly of Cestichis; (2) identify well-supported lineages of the epiphytic group; and (3) re-evaluate the validity of the traditional morphological diagnostic characters of these lineages. On the basis of these results, we proposed taxonomic reclassifications for the species and genera under study.

\section{Materials and methods}

\section{Taxon sampling}

In this investigation, 122 accessions representing 53 species in 7 genera of tribe Malaxideae and three outgroups were sampled. In addition to accessions obtained from previous studies by Cameron (2005), Li and Yan (2013) and Tang et al. (2015), new sequences were generated from recent field collections, including a recently discovered species ( $\mathrm{Li}$ et al. 2019). To evaluate the phylogenetic relationships within the epiphytic Liparis alliance, we used a relatively densetaxon sampling of Cestichis, Platystyliparis and Stichorkis. With the exception of Alatiliparis, nearly all species formerly assigned to segregate genera were sampled. Our sampling included the type species of Cestichis [C. caespitosa (Thouars) Ames], Stichorkis [S. disticha (Thouars) Pfitzer], Liparis [L. loeselii (L.) Rich.] and Oberonia $[O$. iridifolia Roxb. ex Lindl. $=O$. ensiformis (Sm.) Lindl.]. Three representative species of Acanthephippium Blume ex Endl., Collabium Blume, and Eria Lindl. were selected as outgroups as suggested by $\mathrm{Li}$ and Yan (2013). Sequences of Liparis stricklandiana Rchb.f. and L. viridiflora (Blume) Lindl. were already available in GenBank database, but were re-sequenced so as to permit confirmation of their phylogenetic placements. Voucher information and GenBank accession numbers for all taxa considered in this study are listed in Online Resource 1. The data matrices and optimal trees are available in TreeBASE (submission number 25737, accessible at the URL http://purl.org/phylo/treebase/phylows/study/TB2:S2573 7) and are also available from the authors upon request.

\section{DNA extraction, PCR amplification and sequencing}

Total genomic DNA was extracted from fresh leaves using a modified CTAB protocol following Doyle and Doyle (1987). The primer pair 17SE/26SE of Sun et al. (1994) was used for amplification of the ITS region. As described by Whitten et al. (2000) and Cameron (2005), the matK gene region was amplified and sequenced using the primers ny 163 (ACTTCCTCTATCCGCTACTCCTT) and ny166 (CGGATAATGTCCAAATACCAAATA), complemented with two primers, ny 164 (TTGAGCGAACACATT TTTCTATGGAA) and ny165 (ACATAATGTATGAAA GTATMTTTGA). Sequences were initially aligned using MUSCLE (Edgar 2004) as implemented in GENEIOUS and manually adjusted where necessary. 


\section{Phylogenetic analyses}

Trees derived from the individual markers did not show any substantial conflict. No significant incongruences were detected; therefore, we combined the nucleotide sequences of two markers into a single dataset. The concatenated dataset was analyzed with both maximum likelihood (ML) and Bayesian inference (BI) approaches. The ML trees were inferred using the program IQ-TREE 1.6.10 (Nguyen et al. 2015) via the online CIPRES Science Gateway portal (Miller et al. 2010). The best substitution model $(\mathrm{K} 3 \mathrm{Pu}+\mathrm{F}+\mathrm{I}+\mathrm{G} 4)$ was chosen by the ModelFinder option (Kalyaanamoorthy et al. 2017) according to the Bayesian information criteria (BIC) option in IQ-TREE. ML bootstrap with 1000 replicates was used to estimate branch support. BI was implemented in MrBayes v. 3.2.6 (Ronquist et al. 2012) on XSEDE via the CIPRES Science Gateway (Miller et al. 2010). The Markov chain Monte Carlo (MCMC) algorithm was run for $1.0 \times 10^{6}$ generations with four incrementally heated chains, starting from random trees and sampling one out of every 1000 generations. The first $25 \%$ of runs were discarded as burn-in, and the remaining trees were used to construct the $50 \%$ majority rule consensus tree. Bayesian posterior probabilities were used to estimate support for each clade in the consensus tree.

\section{Morphological studies}

This study was mainly based on the examination of herbarium specimens, with their duplicates when available, from the following herbaria: A, AMES, BM, E, G, IBK, IBSC, $\mathrm{K}, \mathrm{L}, \mathrm{P}, \mathrm{PE}$ and SING (herbarium acronyms according to Thiers 2018). Digital images of specimens from A, AMES, BM, BRI, E, G, K, L, NSW, S and W were accessed online at JSTOR Global Plants (http://plants.jstor.org) and Species link (http://splink.cria.org.br). Special attention was paid to type specimens. When possible, information gathered from the literature, living plants cultivated in the experimental greenhouse of South China Botanical Garden, and spiritpreserved flowers were also examined.

\section{Results}

The length of aligned matrix of nrITS was $749 \mathrm{bp}$, while the aligned matK matrix consisted of $1442 \mathrm{bp}$ characters. The ML and Bayesian analyses yielded trees with identical topologies. The ML tree is presented for the discussion of phylogenetic relationships among the Malaxideae, with bootstrap values (BP) and Bayesian posterior probabilities (PP) shown where applicable (Fig. 1). The phylogram of the same tree showing branch lengths is presented in Online Resource 2.

In accordance with previous studies of the tribe Malaxideae, the inferred phylogenetic results strongly support the independent evolution of the same two distinct lineages, A and B, with BS of 100, and PP of 1.00 on both ML and BI trees, respectively. Within the epiphytic lineage A, three major clades (Clade I, II and III) were retrieved in addition to monophyletic Oberonia. All species traditionally allocated to Cestichis cluster into three distinctive clades (Clade I-a, Clade I-c and Clade III). The composition of each clade is explained in detail below (Fig. 1).

Clade I can be considered as the core Cestichis clade, including the majority of Cestichis species. Within this clade, three subclades were recovered. Subclade I-a (PP: 1.00, BP: 100) comprising the generic type of Cestichis was resolved as sister to Subclade I-b with high statistical support (PP: 1.00, BP: 99). Subclade I-b (PP: 1.00, BP: 100) mainly contains species of the Platystylis group, with the addition of two species of sect. Cestichis (Liparis bistriata E.C.Parish \& Rchb.f. and L. elliptica Wight). Subclade I-c (PP: 1.00, BP: 99) includes three species of Cestichis endemic to Australia and New Caledonia, forming a well-supported lineage. This subclade is strongly supported as a sister group in relation to the above-mentioned subclade I-a and I-b (PP: 0.98, BP: 83). The monophyly of Clade II which corresponds to the genus Stichorkis Thouars (du Petit Thouars 1809) or former sect. Distichae Ridl. (Ridley 1886) is robustly supported (PP: 1.00, BP: 100); this group is in turn divided into two smaller subclades. Clade III consists of species corresponding to sect. Blepharoglossum with high node confidence values (PP: 1.00, BP: 100). This group is moderately (ML: 67) or weakly (PP: 0.75) supported as sister to a clade containing entirely species of Oberonia (PP: 1.00, BP: 100) and clearly divergent from the core members of Cestichis and Stichorkis.

Furthermore, Liparis viridiflora (Blume) Lindl. showed considerable incongruence regarding its phylogenetic placement in our preliminary analyses. Identification error is responsible for such a phylogenetic conflict. By sequencing new accessions, the identification of which could be verified by us, it has been proved that the sequences downloaded from GenBank (ITS: AY907107; matK: AY907174) most likely belong to L. condylobulbon Rchb.f. instead of $L$. viridiflora. The latter resembles $L$. viridiflora in gross morphology. Both species have elongated cylindrical pseudobulbs with two terminal leaves. However, these two species differ significantly in their floral morphology. 


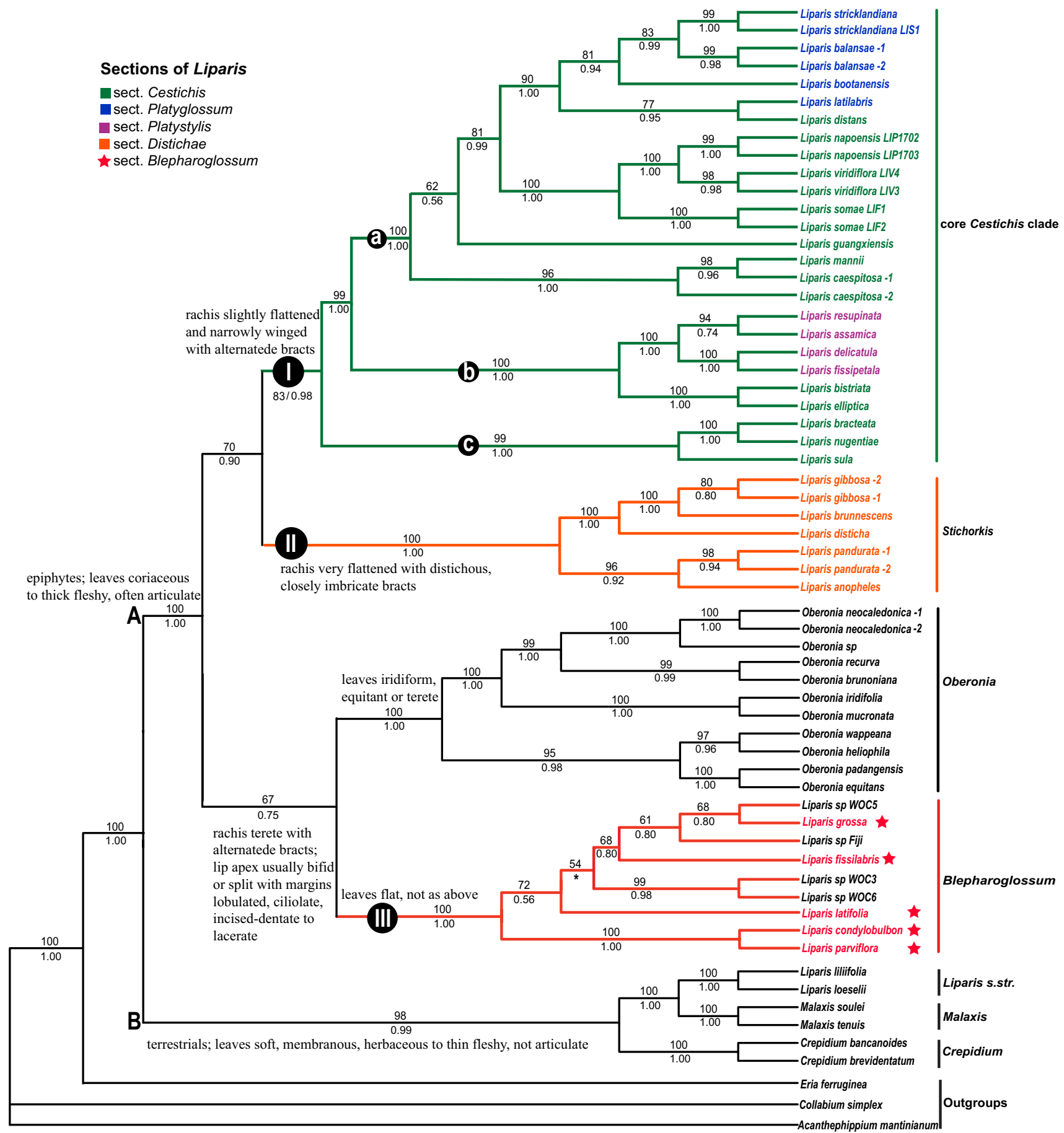

Fig. 1 Maximum-likelihood tree of Cestichis and its allied genera in tribe Malaxideae inferred from the combined analysis of ITS and matK DNA sequences. ML bootstrap support values (bp) and Bayesian posterior probabilities $(\mathrm{pp}) \geq 0.50$ were labeled above and below branches, respectively. Major clades (I-III) that are assigned to differ- ent genera were denoted as different colors. Bold letters signify clades that are discussed in further detail in the text. Sectional taxonomy of Liparis s.l. follows Garay and Romero-Gonzalez (1999). Morphological characters distinguishing each group pertaining to each clade are shown on the left of the cladogram 


\section{Discussion}

\section{Phylogenetic framework}

The phylogeny presented here is largely congruent with previous molecular studies and provides a more detailed view on the relationships between Cestichis and its allied genera within the tribe Malaxideae. Species of Malaxideae fall into either the epiphytic or the terrestrial group, which represent two major evolutionary lineages. Within the main clade A, taxa usually are epiphytes with coriaceous to thick fleshy, articulate leaves, whereas the taxa of the clade B are terrestrials with soft, not articulate leaves.

Clade I mainly contains species classified in the genus Cestichis as defined by Jones and Clements (2005). Our analyses failed to support the monophyly of Cestichis; instead, species corresponding to sect. Blepharoglossum are resolved in Clade III, while the remaining species are scattered in subclades I-a, I-b and I-c. Subclade I-a is well supported, and it represents Cestichis sensu stricto, including its type species $C$. caespitosa (Thouars) Ames [=Liparis caespitosa (Thouars) Lindl.]. Members of subclade I-a belong to Liparis subgenus Cestichis sect. Hologlossum and sect. Platyglossum in previous classification system introduced by Schlechter (1914). In the revised system by Garay and Romero-Gonzalez (1999), these species were assigned to Liparis sect. Cestichis and sect. Platyglossum, respectively. The two sections show a close relationship with some species appears intermediate to various degrees.

Subclade I-b comprises mainly species formerly classified in Liparis sect. Platystylis (Ridley 1886; Garay and Romero-Gonzalez 1999) or the genus Platystyliparis (Margońska 2006), while the other two species (Liparis bistriata and L. elliptica) cluster as a sister clade to the Platystylis group. Platystylis was first introduced as a section of the genus Malaxis by Blume (1825). Lindley (1830) proposed to raise this section to the rank of genus, but Ridley (1886) maintained it as a section of Liparis. Seidenfaden (1976) also mentioned that sect. Platystylis might warrant recognition as a separate genus. Margońska (2006) recognized its generic status and assigned the name Platystyliparis due to the existence of a senior homonym, Platystylis Sweet (Fabaceae). This group is morphologically well differentiated by its relatively short and thick column bearing lateral and ventral wings. These features, however, are partially incongruent with our results, especially concerning the positions of the two species (L. bistriata and L. elliptica).

Subclade I-c, including three species endemic to Australia and New Caledonia, forms a well-supported group (BI: 1.00; ML: 99), sister to subclades I-a plus I-b. This subclade has been identified as a genetically and geographically coherent group. According to Tang (2013), these species differ in having an unlobed lip strongly reflexed from middle. However, this feature is also presented in other lineages of the core Cestichis clade, such as L. bistriata. Thus, there are no significant characters supporting this group as a separate genus.

Although the three subclades I-a, I-b and I-c are highly supported, it is doubtful whether they can be ranked as genera due to the complexity of this large group. The sister relationship of sect. Platystylis and sect. Cestichis was recovered in all analyses. Furthermore, the two species L. bistriata and L. elliptica are the collective sisters of the rest of subclade 1-b; therefore, it will be preferable to include Platystylis as a section of Cestichis rather than to retain it in a separate genus. We propose a generic rank to the Clade I.

In all phylogenetic analyses, the species with distichous, imbricate bracts fell into a single Clade II corresponding to the genus Stichorkis. Stichorkis Thouars (du Petit Thouars1809) is a conserved name with a conserved type against Disticholiparis Marg. \& Szlach. (Margonska and Szlachetko 2004). It is characterized by inflorescence forming compact and articulately laterally flattened spike, distichously arranged bracts.

Clade III comprises species originally placed bySchlechter (1914) in Liparis subgen. Cestichis sect. Blepharoglossum or ascribed to Cestichis sect. Blepharoglossum by Jones and Clements (2005). The genera Stichorkis, Oberonia and the Blepharoglossum clade always appear among the early branching clades within Malaxideae, and the monophyly of the Blepharoglossum clade has been consistently retrieved (Cameron 2005; Li and Yan 2013; Tang 2013; Tang et al. 2015). In our analyses, the Blepharoglossum clade is placed as sister to Oberonia. Although this sister-group relationship is not strongly supported, this position is supported by its unique floral characters. Blepharoglossum has long been recognized as a putative natural group by various authors based on morphological evidence (Schlechter 1914; Van Royen 1979; Jones and Clements 2005), but was never accorded generic rank. The most distinguishing features of Blepharoglossum are its spectacular flowers with brightly orangish red colored, bifid lip often minutely ciliolate along margins. These features resemble those of some species belonging to Oberonia, such as $O$. griffithiana and $O$. rufilabris. In addition, these groups are geographically well isolated and distributed predominantly to the Asia-Pacific islands. The results provide support for the recognition of Blepharoglossum as a distinct genus.

\section{Morphological character patterns}

In this study, we detected and reconsidered the diagnostically important morphological features for the epiphytic genera 
of the Liparis alliance (including Alatiliparis, Blepharoglossum, Cestichis s.s. and Stichorkis). A detailed comparison is attached as the Online Resource 3. The phylogenetic position of Stichorkis is in agreement with its traditional morphological delimitation. Stichorkis can be considered a valid genus, possessing a single autapomorphy. All members of this genus have easily observed laterally flattened spikelike rachis, subtended by distichously arranged and basally imbricate bracts (Pridgeon et al. 2005). These results indicate that the inflorescence morphology and the positioning of flowers especially the arrangement of floral bracts can be considered as taxonomically significant features.

Clade III consists of members generally assigned to sect. Blepharoglossum. These species shared synapomorphy, the presence of conspicuously bifid lip, often with minutely ciliolate margins, which is another important feature used in the delimitation of the major lineages. Our phylogenetic analyses confirm that Blepharoglossum constitutes a single genetically homogeneous cluster. These species are characterized by the racemose inflorescence of multiple attractive orangish red flowers on a terete, not flattened rachis. Lip apex is bifid and minutely lobulated, often finely ciliolate or shortly fringed. The white minute hairs along margins sometimes are barely discernible without magnification. However, vivid colors on the disk and basal channel, occupying the central portion of the lip, ranging from vibrant red, orangish red to brownish red, can help to identify this unique group.

Results of our phylogenetic study also revealed the homoplastic nature of several diagnostic features. The rather short and stout column bearing various laterally and ventral wings or wing-like projections was formerly considered as a synapomorphy for species of sect. Platystylis (Blume 1825) or the genus Platystyliparis (Margońska 2006). The typical stout column with broad wings is usually associated with an auriculate-folded lip, forming obscure convexities or conspicuous rounded auricles. For lack of these distinctive features, L. bistriata and L. elliptica were commonly not regarded as the members of sect. Platystylis. However, our results indicate a sister relationship of these two species with the Platystylis clade (Fig. 1). Given the significant morphological differences between these two species and the Platystylis group, most notably in column details, however, column and column wings cannot serve to diagnose subclade I-b morphologically. It is thus not surprising that a similar situation also occurs in species of Stichorkis. In spite of their markedly imbricate bracts, the species of Stichorkis (Clade II) can be phylogenetically grouped into two smaller subclades (Fig. 1), where various transitional forms related to the column and column wings can be observed. The close affinity between these two distinct subclades is well supported by our molecular data. As mentioned above, the possession of column and wings is not helpful. Considering that many floral variation attributes might be directly related to pollination mechanisms, the short column and folded lip with auricles or convexities may be the result of selection by pollinators. Therefore, these characters may be subject to homoplastic evolution and not indicative of a close phylogenetic relationship.

In addition, Margońska and Szlachetko (2001) recognized Alatiliparis, a small genus of some three species from Sumatra. Its distinguishing features include a relatively short column with two distinctive winged outgrowths on the lateral margins. According to Pridgeon et al. (2005), these may represent an extreme expression of wings. It appears to be most closely related to species assigned to Liparis sect. Platystylis based on similar wings. The generic position of Alatiliparis is still unclear pending further investigation.

\section{Taxonomic treatment}

Blepharoglossum (Schltr.) L.Li, gen. stat. nov. $\equiv$ Liparis Rich. subgen. Cestichis (Thouars ex Pfitzer) Schltr. sect. Blepharoglossum Schltr., Repert. Spec. Nov. Regni. Veg. 1: 199. 1911.-TYPE: Blepharoglossum latifolium (Lindl.) L.Li $\equiv$ Liparis latifolia Lindl. (lectotype, designated by Van Royen 1979).

$=$ Cestichis Thouars ex Pfitzer sect. Blepharoglos sum (Schltr.) M.A.Clem. \& D.L.Jones, Orchadian 15(1): 40. 2005.-TYPE: Liparis parviflora Lindl. (superfluous designation).

Diagnosis: This genus differs from all other genera of the Malaxideae in having the following combination of features: epiphytic herbs with well-developed long ovoid pseudobulbs; coriaceous leaves with prominent midrib; peduncle and rachis terete, wingless, often enclosed by a basal sheathing bract, large and light colored; inflorescence in a more or less dense, cylindrical raceme, often bearing showy, brightly orange-red colored flowers; lip usually strongly deflexed from middle, apex conspicuously bipartite or deeply bilobed with somewhat divergent lobules; lobules often minutely lobulated with ciliate-pubescent margins, sometimes incised-dentate or deeply lacerate, base containing a bilobed callus or two tooth-like thickenings, often longitudinally and shallowly channeled, disk and channel often suffused with bright red or orangish red.

Description: Epiphytic or occasionally lithophytic herbs with distinct rhizomes and well-developed pseudobulbs. Pseudobulbs ovoid to narrowly oblong-ovoid or lageniform, sometimes flattened, broadest basally and tapered toward the apex, usually surrounded by several scarious cataphylls, bearing one or two leaves at the apex. Leaves thin to thick coriaceous, conduplicate, midrib prominent, oblanceolate to elliptic-oblong, apex acute to apiculate. Inflorescence terminal, emerging erect but becoming arcuate to pendulous over mostof their length; peduncle and rachis thick, stout and 
terete, pale glaucous green, basally often enveloped in one or more large sheathing bracts, light colored and conspicuous; rachis obscurely sulcate, wingless, bearing 10 to more than 40 flowers in a more or less dense, cylindrical raceme. Floral bracts much shorter than pedicellate ovary, narrowly lanceolate. Flowers resupinate, greenish to brownish orange, often bearing a lip in vivid and striking colors. Sepals lanceolate to elliptic-oblong, somewhat obtuse, strongly reflexed. Petals narrowly linear to linear, spreading but a little reflexed. Lip usually strongly recurved downward from middle, base containing a bilobed callus or two tooth-like thickening, usually with a broad, longitudinal channel in the centre, over most of the length of the lip, tinged with scarlet or orangish red from base to middle, sometimes extending to the apex; apex conspicuously bipartite or deeply divided; apical lobules divergent, suboblong, minutely lobulated with finely ciliolate margins, sometimes erose-dentate, sharply toothed or deeply lacerate. Column more or less arcuate, thickened and laterally dilated near base, apex inconspicuously winged. Pollinia four in two subequally sized pairs, caudicle and viscidium absent. Capsule obovoid.

Distribution: A paleotropical genus of some 26 species, well represented in tropical Asia-Pacific islands, e.g., Peninsular Malaysia, Borneo, Sumatra, Java, Sulawesi, the Philippines, Papua New Guinea, New Caledonia and Fiji, with some species found in Myanmar, Thailand, Vietnam, Taiwan and Hainan Islands of China.

Blepharoglossum bicolor (J.J.Sm.) L.Li, comb. nov. $\equiv$ Liparis bicolor J.J.Sm., Fl. Buitenzorg 6: 270. 1905. 三Stichorkis bicolor (J.J.Sm.) Marg., Szlach. \& Kulak, Acta Soc. Bot. Poloniae 77: 37. 2008.-TYPE: Indonesia, Java, Salak, cult. in Hort. Bogor, s.col., s.n. (holotype: BO [n.v.]; isotype: AMES00100786!).

Blepharoglossum bicuspidatum (J.J.Sm.) L.Li, comb. nov. 三Liparis bicuspidata J.J.Sm., Icon. Bogor. 2: 45. t. 109-C. 1903. 三Stichorkis bicuspidata (J.J.Sm.) Marg., Szlach. \& Kulak, Acta Soc. Bot. Poloniae 77: 37. 2008.—TYPE: Borneo, Kalimantan, s.loc., A.W. Nieuwenhuis s.n. (holotype: BO [n.v.]).

= Liparis wenzelii Ames, Orchidaceae 5: 84. 1915.TYPE: Philippines, Leyte, C.A. Wenzel 0403 (holotype: AMES00100999!).

Blepharoglossum condylobulbon (Rchb.f.) L.Li, comb. nov. E Liparis condylobulbon Rchb.f., Hamb. Gartenz. 18: 34. 1862. 三Leptorkis condylobulbon (Rchb.f.) Kuntze, Revis. Gen. Pl. 2: 671. 1891. 三 Cestichis condylobulbon (Rchb.f.) M.A.Clem. \& D.L.Jones, Orchadian 15: 40. 2005. 三Stichorkis condylobulbon (Rchb.f.) Marg., Szlach. \& Kulak, Acta Soc. Bot. Poloniae 77: 37. 2008.-TYPE:
Indonesia, Java, s.loc., cult., G.W. Schiller s.n., Herb. Reichenbach 46205 (holotype: W[n.v.]).

= Liparis nesophila Rchb.f., Otia Bot. Hamburg. 1: 56. 1878.-TYPE: Fiji Islands, B.C. Seemann 614 (holotype: K000943538!; isotypes: P00311546!, AMES [photo!]).

$=$ Liparis persimilis Schltr., Repert. Spec. Nov. Regni. Veg. 1: 206. 1911. ECestichis persimilis (Schltr.) M.A.Clem. \& D.L.Jones, Orchadian 15: 40. 2005. EStichorkis persimilis (Schltr.) Marg., Szlach. \& Kulak, Acta Soc. Bot. Poloniae 77: 39. 2008.-TYPE: Papua New Guinea, F.R.R. Schlechter 18999 (holotype: B, destroyed; isotypes: AMES00100923!, AMES00100924!, E00146323!, K000943198!, L0061523!, L0061524!, S-G6 883 !).

= Liparis dolichopoda Hayata, Icon. Pl. Formosan. 4: 27. t.5. 1914.-TYPE: China, Taiwan, s.loc., cult. in seminario Taihoku, B. Hayata s.n. (holotype: TNS [n.v.]).

= Liparis clemensiae (Ames) Ames, Orchidaceae 5: 79. 1915. 三Cestichis clemensiae Ames, Philipp. J. Sci. 4: 666. 1910.-TYPE: Philippines, Mindanao, Lake Lanao, M.S. Clemens 129 (holotype: AMES[n.v.]).

Blepharoglossum crenulatum (Blume) L.Li, comb. nov. 三 Malaxis crenulata Blume, Bijdr. Fl. Ned. Ind. 8: 393. 1825. $\equiv$ Liparis crenulata (Blume) Lindl., Gen. Sp. Orchid. Pl. 30. 1830. ELeptorkis crenulata (Blume) Kuntze, Revis. Gen. P1. 2: 671. 1891. EStichorkis crenulata (Blume) Marg., Szlach. \& Kulak, Acta Soc. Bot. Poloniae 77: 37. 2008.TYPE: Indonesia, Java, Mt. Gegar Bintang, C.L. Blume 494 (holotype: L0061538!).

Blepharoglossum elegans (Lindl.) L.Li, comb. nov. $\equiv$ Liparis elegans Lindl., Gen. Sp. Orchid. Pl. 30. 1830. इLeptorkis elegans (Lindl.) Kuntze, Revis. Gen. P1. 2: 671. 1891. $\equiv$ Cestichis elegans (Lindl.) M.A.Clem. \& D.L.Jones, Orchadian 15: 39. 2005. 三Stichorkis elegans (Lindl.) Marg., Szlach. \& Kulak, Acta Soc. Bot. Poloniae 77: 38. 2008.TYPE: Malaysia, Penang, G. Porter, Wallich Cat. no. 1943 (holotype: K001114788!).

= Liparis gracilis Hook.f., Hooker's Icon. Pl. 21: t. 2011. 1890; Fl. Brit. Ind. 6: 182. 1890. 三Leptorkis gracilis (Hook.f.) Kuntze, Rev. Gen. Pl. 2: 671. 1891.-TYPE: Malaysia, Waterfall hill, J.L. Wray 2920 (holotype: K000943022!).

= Liparis stenostachya Schltr., Repert. Spec. Nov. Regni. Veg. 1: 207. 1911. 三 Cestichis stenostachya (Schltr.) M.A.Clem. \& D.L.Jones, Orchadian 15: 40. 2005. EStichorkis stenostachya (Schltr.) Marg., Szlach. \& Kulak, Acta Soc. Bot. Poloniae 77: 39. 2008.-TYPE: Papua New Guinea, F.R.R. Schlechter 17423 (syntype: B, destroyed; isosyntypes: AMES00100984!, E00146325!, G00354679!, L0535763!, NSW926705!, S-G6880! ); F.R.R. Schlechter 19281 (syntype: B, destroyed), 
F.R.R. Schlechter 19395 (syntype: B, destroyed; isosyntypes: G00354677!, L0535761!).

$=$ Liparis indifferens J.J.Sm., Repert. Spec. Nov. Regni. Veg. 12: 24. 1913. . Cestichis indifferens (J.J.Sm.) M.A.Clem. \& D.L.Jones, Orchadian 15: 40. 2005. EStichorkis indifferens (J.J.Sm.) Marg., Szlach. \& Kulak, Acta Soc. Bot. Poloniae 77: 38. 2008.—TYPE: Bogor cult., K. Gjellerup 310 (holotype: BO [n.v.]; isotype: L0061547!).

Blepharoglossum fissilabrum (T.Tang \& F.T.Wang) L.Li, comb. nov. $\equiv$ Liparis fissilabris T.Tang \& F.T.Wang, Acta Phytotax. Sin. 12: 37. 1974.-TYPE: China, Hainan, Po-ting [Baoting], F.C. How 73978 (holotype: PE00341881!; isotypes: AMES00100831!, IBK00191801!, IBK00191802!, IBSC0636554!, IBSC0636555!).

Blepharoglossum foetulentum (J.J.Sm.) L.Li, comb. nov. $\equiv$ Liparis foetulenta J.J.Sm., Bull. Jard. Bot. Buitenzorg, sér. 3, 1: 32. 1920. EStichorkis foetulenta (J.J.Sm.) Marg., Szlach. \& Kulak, Acta Soc. Bot. Poloniae 77: 38. 2008.-TYPE: Malaysia, Mentawei Islands, cult. in Hort. Bogor, J.F.K. Hansen s.n. (holotype: BO [n.v.]; isotypes: L0063331!, L0063332!)

= Liparis klossii Ridl., Bull. Misc. Inform. Kew 84. 1926.TYPE: Indonesia, Sumatra, Siberut Island, C.B. Kloss 14502 (holotype: SING0047445!).

Blepharoglossum grandiflorum (Ridl.) L.Li, comb. nov. $\equiv$ Liparis grandiflora Ridl., J. Bot. 22: 333. 1884. $\equiv$ Leptorkis grandiflora (Ridl.) Kuntze, Revis. Gen. Pl. 2: 671. 1891. 三Stichorkis grandiflora (Ridl.) Marg., Szlach. \& Kulak, Acta Soc. Bot. Poloniae 77: 38. 2008.-TYPE: Borneo, Sarawak, Mindai-Pramassan, Grabowsky s.n.(holotype: BM000088712!).

Blepharoglossum grossum (Rchb.f.) L.Li, comb. nov. $\equiv$ Liparis grossa Rchb.f., Gard. Chron., n.s. 19: 110. 1883. $\equiv$ Leptorkis grossa (Rchb.f.) Kuntze, Revis. Gen. Pl. 2: 671. 1891. EStichorkis grossa (Rchb.f.) Marg., Szlach. \& Kulak, Acta Soc. Bot. Poloniae 77: 38. 2008.—TYPE: Myanmar, s.loc., imported to England by Low anno 1882, Herb. Reichenbach 46236 (holotype: W [n.v.]).

Blepharoglossum kinabaluense (J.J.Wood) L.Li, comb. nov. $\equiv$ Liparis kinabaluensis J.J.Wood, Lindleyana 5(2): 84. 1990. $\equiv$ Stichorkis kinabaluensis (J.J.Wood) Marg., Szlach. \& Kulak, Acta Soc. Bot. Poloniae 77: 38. 2008.—TYPE: Malaysia, Borneo, Sabah, Mt. Kinabalu, Penibukan Ridge, east of Dahobang River, J. Clemens \& M.S. Clemens 50099 (holotype: K000943238!; isotypes: AMES00112760!, BM000088855!).
Blepharoglossum laceratum (Ridl.) L.Li, comb. nov. 三Liparis lacerata Ridl., J. Linn. Soc. Bot. 22: 284. 1886. $\equiv$ Leptorkis lacerata (Ridl.) Kuntze, Revis. Gen. Pl. 2: 671. 1891. EStichorkis lacerata (Ridl.) Marg., Szlach. \& Kulak, Acta Soc. Bot. Poloniae 77: 38. 2008.—TYPE: Malaysia, Borneo, Lawas River, Burbidge s.n. (holotype: BM [photo!]).

Blepharoglossum latifolium (Lind1.) L.Li, comb. nov. $\equiv$ Malaxis latifolia Blume, Bijdr. Fl. Ned. Ind. 8: 393. 1825, nom. illeg. (non Smith 1812) ELiparis latifolia Lindl., Gen. Sp. Orchid. Pl. 30. 1830. ECestichis latifolia (Lindl.) Pfitzer, Nat. Pflanzenfam. 2: 6: 131. 1888. =Leptorkis latifolia (Lindl.) Kuntze, Revis. Gen. Pl. 2: 671. 1891. EStichorkis latifolia (Lindl.) Pfitzer, Nat. Pflanzenfam. 1: 103. 1897. $\equiv$ Cestichis latifolia (Blume) M.A.Clem. \& D.L.Jones, Orchadian 15: 40. 2005, comb. illeg.-TYPE: Indonesia, Java, Bantam, Mt. Pantjat, C.L.Blume s.n. (holotype: BO [n.v.]; isotype: L0063951!).

= Liparis robusta Hook.f., Hooker's Icon. Pl. 21: t. 2012. 1890._TYPE: Malaysia, Perak, Maxwell Hill, J.L. Wray 2808 (holotype: K000943023!).

Blepharoglossum mentaweiense (J.J.Sm.) L.Li, comb. nov. $\equiv$ Liparis mentaweiensis J.J.Sm., Bull. Jard. Bot. Buitenzorg, sér. 3, 2: 32. 1920.-TYPE: Indonesia, West Sumatra, Mentawei Islands, cult. in Hort. Bogor, J.F.K. Hansen s.n. (holotype: $\mathrm{BO}$ [n.v.]).

Blepharoglossum merapiense (Schltr.) L.Li, comb. nov. $\equiv$ Liparis merapiensis Schltr., Bot. Jahrb. Syst. 45: 16. 1911. ECestichis merapiensis (Schltr.) M.A.Clem. \& D.L.Jones, Orchadian 15: 40. 2005. EStichorkis merapiensis (Schltr.) Marg., Szlach. \& Kulak, Acta Soc. Bot. Poloniae 77: 38. 2008.-TYPE: Indonesia, Sumatra, F.R.R. Schlechter 15959 (holotype: B, destroyed).

Blepharoglossum microblepharon (Schltr.) L.Li, comb. nov. $\equiv$ Liparis microblepharon Schltr., Repert. Spec. Nov. Regni. Veg. 1: 205. 1911. ECestichis microblepharon (Schltr.) M.A.Clem. \& D.L.Jones, Orchadian 15: 40. 2005. $\equiv$ Stichorkis microblepharon (Schltr.) Marg., Szlach. \& Kulak, Acta Soc. Bot. Poloniae 77: 38. 2008.-TYPE: Papua New Guinea, F.R.R. Schlechter 19413 (holotype: B, destroyed; isotypes: K000943183!, E00146311!, G00354682!, L0061575!, L0061576!, NSW926655!, S-G 6891 !).

Blepharoglossum palawanense (Ames) L.Li, comb. nov. $\equiv$ Liparis palawanensis Ames, Sched. Orchi. 6: 39. 1923.TYPE: Philippines, Palawan Island, Alfonzo XIII forest, C.M. Weber 612 (holotype: AMES00100920!). 
Blepharoglossum pallidum (Blume) L.Li, comb. nov. 三 Malaxis pallida Blume, Bijdr. Fl. Ned. Ind. 8: 391. 1825. $\equiv$ Liparis pallida (Blume) Lindl., Gen. Sp. Orchid. Pl. 30. 1830. $\equiv$ Leptorkis pallida (Blume) Kuntze, Revis. Gen. Pl. 2: 671. 1891. EStichorkis pallida (Blume) Marg., Szlach. \& Kulak, Acta Soc. Bot. Poloniae 77: 39. 2008.—TYPE: Indonesia, Java, Salak, s.col., s.n. (holotype: L0061522!).

Blepharoglossum parviflorum (Blume) L.Li, comb. nov. 三 Malaxis parviflora Blume, Bijdr. Fl. Ned. Ind. 8: 392. 1825. 三Liparis parviflora (Blume) Lindl., Gen. Sp. Orchid. Pl. 31. 1830. ELeptorkis parviflora (Blume) Kuntze, Revis. Gen. Pl. 2: 671. 1891. ECestichis parviflora (Blume) M.A.Clem.\&D.L.Jones, Orchadian 15: 39. 2005. EStichorkis parviflora (Blume) Marg., Szlach. \& Kulak, Acta Soc. Bot. Poloniae 77: 39. 2008.-TYPE: Indonesia, Java, Salak, s.col., s.n. (holotype: L0061187!).

= Liparis dissitiflora Ridl., Bull. Misc. Inform. Kew 85. 1926.-TYPE: Indonesia, Sumatra, Siberut Island, C.B. Kloss 14632 (holotype: SING0047444!; isotype: K000943232!).

Blepharoglossum rhodochilum (Rolfe) L.Li, comb. nov. $\equiv$ Liparis rhodochila Rolfe, Bull. Misc. Inform. Kew 412. 1908.-TYPE: Indonesia, Java, s.col., s.n.(holotype: K000943229!).

Blepharoglossum rhombeum (J.J.Sm.) L.Li, comb. nov. $\equiv$ Liparis rhombea J.J.Sm., Bull. Dép. Agric. Indes Néerl. 43: 35. 1910. EStichorkis rhombea (J.J.Sm.) Marg., Szlach. \& Kulak, Acta Soc. Bot. Poloniae 77: 39. 2008.-TYPE: Indonesia, Java, Salak, cult., Joseph s.n. (holotype: L [n.v.]).

Blepharoglossum schistochilum (Schltr.) L.Li, comb. nov. $\equiv$ Liparis schistochila Schltr., Repert. Spec. Nov. Regni. Veg. 3: 81. 1906. ECestichis schistochila (Schltr.) M.A.Clem. \& D.L.Jones, Orchadian 15: 39. 2005. इLiparis pectinifera Schltr., Fl. Schutzgeb. Südsee. 105. 1905, nom. illeg. (non Ridl. 1898).-TYPE: Papua New Guinea, F.R.R. Schlechter 13950 (holotype: B, destroyed).

Blepharoglossum serrulatum (Schltr.) L.Li, comb. nov. $\equiv$ Liparis serrulata Schltr., Fl. Schutzgeb. Südsee. 106. 1905. ECestichis serrulata (Schltr.) M.A.Clem. \& D.L.Jones, Orchadian 15: 40. 2005. $\equiv$ Stichorkis serrulata (Schltr.) Marg., Szlach. \& Kulak, Acta Soc. Bot. Poloniae 77: 39. 2008.—TYPE: Papua New Guinea, Torricelli-Gebirge, F.R.R. Schlechter 14328 (holotype: B, destroyed; isotypes: K000943176!, P00360845!).

Blepharoglossum spectabile (Schltr.) L.Li, comb. nov. $\equiv$ Liparis spectabilis Schltr., Repert. Spec. Nov.
Regni. Veg. 1: 204. 1911. ECestichis spectabilis (Schltr.) M.A.Clem. \& D.L.Jones, Orchadian 15: 40. 2005. $\equiv$ Stichorkis spectabilis (Schltr.) Marg., Szlach. \& Kulak, Acta Soc. Bot. Poloniae 77: 39. 2008.—TYPE: Papua New Guinea, Kani-Gebirges, F.R.R. Schlechter 17060 (syntype: B, destroyed; isosyntypes: AMES00100982!, AMES00100983!, E00146324!, G00354681!, K000943175!, L0061529!, L0061530!, L0061531!, NSW926704!, S-G6882!) F.R.R.Schlechter 19027 (syntype: B, destroyed).

Blepharoglossum trichechum (J.J.Sm.) L.Li, comb. nov. $\equiv$ Liparis trichechus J.J.Sm., Bull. Jard. Bot. Buitenzorg, sér. 2, 25: 24. 1917.-TYPE: Indonesia, Sumatra, Bengkulu, Rimbo Pengadang, cult. in Hort Borg., Ajoeb $749 T$ (holotype: BO [n.v.]; isotype: L0061583!).

Blepharoglossum trichoglotte (Ames) L.Li, comb. nov. $\equiv$ Cestichis trichoglottis Ames, Orchidaceae 2: 139. 1908. $\equiv$ Liparis trichoglottis (Ames) Schltr., Repert. Spec. Nov. Regni. Veg. 1: 203. 1911.-TYPE:Philippines, Lake Lanao, Mindanao, M.S. Clemens 131 (holotype: AMES [n.v.]).

Blepharoglossum werneri (Schltr.) L.Li, comb. nov. $\equiv$ Liparis werneri Schltr., Repert. Spec. Nov. Regni. Veg. 1: 250. 1911. $\equiv$ Cestichis werneri (Schltr.) M.A.Clem. \& D.L.Jones, Orchadian 15: 40. 2005.-TYPE: Papua New Guinea, Gelu Peak, Werner 45 (holotype: B, destroyed); Pengagl Creek, Millar and N.G.F. Van Royen 14965 (neotype designated by Van Royen 1979: L[n.v.]; isoneotypes: A00101000!, K000943549!, K000943550!, BRI [photo!]).

Notes: Seidenfaden (1976) mentioned that species Liparis beccarii Ridl. is closely related to Liparis crenulata (Blume) Lindl., but differ in the lip shape. In fact, there is a considerable difference in the lip detail based on the comparisons of type specimens. It can be distinguished by the lip base not concave or channeled, without any callus or ridges and the much smaller, not divergent apical lobules with margins only minutely toothed. Liparis beccarii is so far only known from Mt. Singgalang in west Sumatra. Due to limited specimen and morphological incongruence, we have excluded this species here pending more information.

Acknowledgements We sincerely thank Dr. Jin Xiao-Hua (Institute of Botany, CAS) and Dr. Tang Guang-Da (South China Agricultural University) for providing us with some studies and valuable discussions. We are indebted to Dr. Yang Chih-Kai (National Taiwan University) for his help in the preliminary work and Mr. Qin Ming for his technical assistance of this study. We are grateful to editors Dr. Michal Ronikier, Prof. Karol Marhold and two anonymous reviewers for their constructive comments that improved the paper. We would also like to thank the curators and staff of the following herbaria: A, AMES, BM, BRI, E, G, IBK, IBSC, K, L, NSW, P, PE, S, SING and W. This research was financially supported by grants from the National Natural Science Foundation of China (Nos. 31770215 and 31670193) and Science and 
Technology Basic Work, Project of the Ministry of Science and Technology, China (No. 2013FY112100).

Open Access This article is licensed under a Creative Commons Attribution 4.0 International License, which permits use, sharing, adaptation, distribution and reproduction in any medium or format, as long as you give appropriate credit to the original author(s) and the source, provide a link to the Creative Commons licence, and indicate if changes were made. The images or other third party material in this article are included in the article's Creative Commons licence, unless indicated otherwise in a credit line to the material. If material is not included in the article's Creative Commons licence and your intended use is not permitted by statutory regulation or exceeds the permitted use, you will need to obtain permission directly from the copyright holder. To view a copy of this licence, visit http://creativecommons.org/licenses/by/4.0/.

\section{Information on Electronic Supplementary Mate- rial}

Online Resource 1. A list of species sampled, vouchers and GenBank accession numbers.

Online Resource 2. The ML phylogram showing branch lengths inferred from a combined dataset of ITS and matK DNA sequences.

Online Resource 3. Distinguishing morphological characteristics of Cestichis s.s. and closely related genera.

\section{References}

Blume CL (1825) Bijdragen tot de Flora van Nederlandsch Indië, vol. 7. Ter Lands Drukkerij, Batavia. https://doi.org/10.5962/bhl.title.395

Cameron KM (2005) Leave it to the leaves: a molecular phylogenetic study of Malaxideae (Epidendroideae, Orchidaceae). Amer J Bot 92:1025-1032

Chen SC, Liu ZJ, Zhu GH, Lang KY, Ji ZH, Luo YB, Jin XH, Cribb PJ, Wood JJ, Gale SW, Ormerod P, Vermeulen JJ, Wood HP, Clayton D, Bell A (2009) Orchidaceae. In: Wu ZY, Raven PH, Hong DY (eds) Flora of China, vol. 25. Science Press, Beijing \& Missouri Botanical Garden Press, St. Louis, pp 211-228

Comber JB (2001) Liparis Rich. In: Orchids of Sumatra. Natural History Publications, Kota Kinabalu, Borneo, in association with the Royal Botanic Gardens, Kew, Richmond \& the National Parks Board, Singapore Botanic Gardens, Singapore, pp 136-169

Doyle JJ, Doyle JL (1987) A rapid DNA isolation procedure for small quantities of fresh leaf tissue. Phytochem Bull 19:11-15

du Petit Thouars A (1809) Extrait de trois Memoires lus a la premiere classe delílnstitut, sur líhistoire des plantes orchidees des iles australes d'Afrique. Nouv Bull Sci Soc Philom Paris 1:314-319

Edgar RC (2004) MUSCLE: multiple sequence alignment with high accuracy and high throughput. Nucl Acids Res 32:1792-1797. https://doi.org/10.1093/nar/gkh340

Garay LA, Romero-Gonzalez GA (1999) Schedulae Orchidum II. Harvard Pap Bot 4:475-488

Jones DL, Clements MA (2005) Miscellaneous nomenclature notes and changes in Australian, New Guinea and New Zealand Orchidaceae. The Orchiadian 15:33-42

Kalyaanamoorthy S, Minh BQ, Wong TFK, von Haeseler A, Jermiin LS (2017) ModelFinder: fast model selection for accurate phylogenetic estimates. Nature Meth 14:587-589. https://doi. org/10.1038/nmeth.4285

Li L, Yan HF (2013) A remarkable new species of Liparis (Orchidaceae) from China and its phylogenetic implications. PLoS ONE 8:e78112. https://doi.org/10.1371/journal.pone.0078112
Li L, Chuang SW, Li B, Zeng SJ, Yan HF, Li SJ (2019) Liparis napoensis (Orchidaceae), a new species from Guangxi, China. Phytokeys 119:31-37. https://doi.org/10.3897/phytokeys.119.32041

Lindley J (1830) The genera and species of orchidaceous plants. Ridgways, Piccadilly

Margońska HB (2006) Platystyliparis Margońska—un genre nouveau de la sous-tribu Malaxidinae. Richardiana 7:33-41

Margońska HB, Szlachetko DL (2001) Alatiliparis (Orchidaceae: Malaxidinae), a new orchid genus with two species from Sumatra. Ann Bot Fenn 38:77-81

Margońska HB, Szlachetko DL (2004) Disticholiparis, a new genus of subtribe Malaxidinae (Orchidales, Orchidaceae). Die Orchidee 55:175-179

Miller MA, Pfeiffer W, Schwartz T (2010) Creating the CIPRES Science Gateway for inference of large phylogenetic trees. In: Nelson CR (ed) Proceedings of the gateway computing environments workshop (GCE). Curran Associates Inc., New Orleans, pp 1-8. https://doi.org/10.1109/gce.2010.5676129

Nguyen L-T, Schmidt HA, von Haeseler A, Minh BQ (2015) IQ-TREE: a fast and effective stochastic algorithm for estimating maximum likelihood phylogenies. Molec Biol Evol 32:268-274. https://doi. org $/ 10.1093 / \mathrm{molbev} / \mathrm{msu} 300$

Pearce NP, Cribb PJ (2002) Flora of Bhutan, vol. 3. Part 3: the orchids of Bhutan. Royal Botanica Garden \& Royal Government of Bhutan, Edinburgh \& Thimbu, pp 195-212

Pfitzer E (1887) Entwurf einer Natürlichen Arnordnung der Orchideen. C. Winter's Universitäts-Buchhandlung, Heidelberg

Pridgeon AM, Cribb PJ, Chase MW, Rasmussen FN (2005) Genera Orchidacearum, vol. 4. Part 1: Epidendroideae. Oxford University Press, New York

Ridley HN (1886) A monograph of the genus Liparis. J Linn Soc Bot 22:244-297. https://doi.org/10.1111/j.1095-8339.1886.tb00468.x

Ronquist F, Klopfstein S, Vilhelmsen L, Schulmeister S, Murray DL, Rasnitsyn AP (2012) A total-evidence approach to dating with fossils, applied to the early radiation of the Hymenoptera. Syst Biol 61:973-999. https://doi.org/10.1093/sysbio/sys058

Schlechter R (1911-1914) Die Orchidaceen von Deutsch-Neu-Guinea. Repert Spec Nov Regni Veg Beih 1: i-lxvi, 1-1079

Seidenfaden G (1976) Orchid Genera in Thailand IV. Liparis L. C. Rich. Dansk Bot Ark 31:1-105

Sun Y, Skinner DZ, Liang GH, Hulbert SH (1994) Phylogenetic analysis of Sorghum and related taxa using internal transcribed spacers of nuclear ribosomal DNA. Theor Appl Genet 89:26-32. https:// doi.org/10.1007/BF00226978

Tang GD (2013) Systematics of Liparis and its alliance. PhD Thesis, South China Agricultural University, Guangzhou (in Chinese)

Tang GD, Zhang GQ, Hong WJ, Liu ZJ, Zhuang XY (2015) Phylogenetic analysis of Malaxideae (Orchidaceae: Epidendroideae): two new species based on the combined nrDNA ITS and chloroplast matK sequences. Guihaia 35:447-463. https://doi.org/10.11931/ guihaia.gxzw201506015

Thiers B (2018) Index Herbariorum: a global directory of public herbaria and associated staff. New York Botanical Garden's Virtual Herbarium, Bronx. Available at: http://sweetgum.nybg.org/ih/

Van Royen P (1979) The Alpine Flora of New Guinea 2. J. Cramer, Vaduz

Whitten WM, Williams NH, Chase MW (2000) Subtribal and generic relationships of Maxillarieae (Orchidaceae) emphasis on Stanhopeinae: combined molecular evidence. Amer J Bot 87:1842-1856. https://doi.org/10.2307/2656837

Publisher's Note Springer Nature remains neutral with regard to jurisdictional claims in published maps and institutional affiliations. 